\title{
PENERAPAN MODEL GUIDED DISCOVERY LEARNING DENGAN BANTUAN MEDIA KARTU PEMBELAJARAN UNTUK MENINGKATKAN AKTIVITAS DAN PRESTASI BELAJAR KIMIA PADA MATERI POKOK REAKSI REDOKS SISWA KELAS X MIPA 3 SEMESTER GENAP SMA NEGERI 2 SURAKARTA TAHUN PELAJARAN 2016/2017
}

\author{
Latifah Suryaningrum, Ashadi ${ }^{\star}$, dan Bakti Mulyani
}

Program Studi Pendidikan Kimia, FKIP, Universitas Sebelas Maret, Surakarta, Indonesia

* Keperluan korespondensi, HP 0816671690, e-mail: ashadiuns2014@gmail.com

\begin{abstract}
ABSTRAK
Penelitian ini bertujuan untuk meningkatkan aktivitas dan prestasi belajar siswa pada materi pokok reaksi redoks kelas X MIPA 3 SMA Negeri 2 Surakarta melalui penerapan model guided discovery learning berbantu media kartu pembelajaran. Penelitian ini merupakan jenis penelitian tindakan kelas (PTK) yang dilaksanakan dalam dua siklus, dengan tiap siklus terdiri atas perencanaan, pelaksanaan, observasi, dan refleksi. Subjek penelitian adalah siswa kelas $X$ MIPA 3 SMA Negeri 2 Surakarta tahun pelajaran 2016/2017. Objek penelitian adalah aktivitas dan prestasi belajar siswa. Sumber data berasal dari guru dan siswa. Teknik pengumpulan data melalui observasi, wawancara, tes, angket, dan studi dokumentasi, selanjutnya dianalisis menggunakan metode deskriptif kualitatif. Validitas data menggunakan teknik triangulasi. Berdasarkan hasil penelitian dapat disimpulkan bahwa penerapan model guided discovery learning dengan bantuan media kartu pembelajaran dapat meningkatkan aktivitas dan prestasi belajar siswa pada materi pokok reaksi redoks. Persentase ketercapaian aktivitas belajar siswa saat siklus I sebesar $82,35 \%$ meningkat menjadi $94,12 \%$ pada siklus II. Sedangkan untuk prestasi belajar aspek pengetahuan pada siklus I sebesar $58,82 \%$ meningkat menjadi $85,65 \%$ pada siklus II, aspek sikap sebesar $97,06 \%$ pada siklus I, dan aspek keterampilan sebesar $100 \%$ pada siklus I.
\end{abstract}

Kata kunci : guided discovery learning, aktivitas belajar, prestasi belajar, redoks, kartu

\section{PENDAHULUAN}

Berbicara mengenai perkembangan Indonesia, pasti tidak bisa lepas menyangkut aspek pendidikan. Pendidikan merupakan salah satu faktor penting untuk mendapatkan pengakuan sebuah negara. Dengan pendidikan yang baik diharapkan akan melahirkan generasi penerus bangsa yang cerdas dan kompeten dalam bidangnya. Berdasarkan hasil studi dari PISA (Program for International Student Assessment) pada siswa kelas VIII tahun 2015 untuk Indonesia diperoleh hasil rerata prestasi sains sebesar 403. Masih pada tahun yang sama untuk negaranegara Asia seperti Thailand memiliki skor rerata prestasi sains sebesar 421 ,
Korea sebesar 516, Vietnam sebesar 525, Jepang sebesar 538 dan Singapura sebesar 556 [1]. Hal ini menunjukkan kualitas pendidikan di Indonesia sendiri tertinggal dari negara-negara lain. Salah satu tindakan yang ditempuh pemerintah untuk mengatasi masalah tersebut yaitu adanya pengembangan kurikulum pendidikan. Saat ini diterapkan dua kurikulum yakni Kurikulum Tingkat Satuan Pendidikan (KTSP) dan Kurikulum 2013 [2].

Mata pelajaran kimia merupakan salah satu mata pelajaran sains wajib di Sekolah Menengah Atas (SMA) khususnya pada kelas peminatan MIPA. Kimia merupakan mata pelajaran yang memiliki karakteristik perpaduan antara 
teori dan aktivitas ilmiah. Teori dalam kimia ini dapat berupa pemahaman suatu konsep yang dapat diberikan oleh guru kepada siswa melalu penjelasan. Sedangkan untuk aktivitas ilmiah dalam mata pelajaran kimia berupa penelitian atau eksperimen yang dapat mendorong siswa untuk belajar menemukan. Oleh karena itu, seorang guru diharapkan mampu menyajikan materi kimia dalam suatu pembelajaran yang sesuai dengan karakteristik kimia tersebut.

SMAN 2 Surakarta merupakan salah satu sekolah yang melanjutkan untuk menerapkan kurikulum 2013. Kurikulum 2013 menuntut agar pembelajaran berpusat pada siswa (student centered learning). Akan tetapi pada kenyataannya pembelajaran di sekolah masih terpusat pada guru (teacher centered learning) terlihat dari kurangnya aktivitas belajar siswa.

Hasil wawancara yang dilakukan dengan guru mata pelajaran Kimia di SMAN 2 Surakarta pada tanggal 12 September 2016, permasalahan yang dialami salah satunya terjadi pada bab reaksi redoks. Pokok bahasan materi reaksi redoks merupakan materi yang sulit karena memiliki karakteristik abstrak, konsep yang berhubungan dan hitungan. Selain itu didapatkan data pendukung berupa presentase daya serap siswa pada Ujian Nasional tahun pelajaran $2014 / 2015$ pada materi redoks didapatkan hasil sebesar 48,28\%[3]. Kemudian didukung oleh data lain yaitu ketuntasan belajar siswa kelas X MIPA pada materi ulangan reaksi redoks tahun ajaran 2014/2015 dan 2015/2016 disajikan dalam Tabel 1.

Tabel 1. Ketuntasan Belajar Ulangan Reaksi Redoks Tahun Ajaran 2014/2015 dan 2015/2016

\begin{tabular}{ccc}
\hline \multirow{2}{*}{ Kelas } & \multicolumn{2}{c}{$\begin{array}{c}\text { \% Ketuntasan } \\
\text { Tahun Ajaran }\end{array}$} \\
\cline { 2 - 3 } & $2014 / 2015$ & $2015 / 2016$ \\
\hline X MIPA 1 & 25,00 & 21,43 \\
X MIPA 2 & 6,89 & 28,57 \\
X MIPA 3 & 13,79 & 9,67 \\
X MIPA 4 & 25,00 & 35,48 \\
X MIPA 5 & 13,33 & 41,38 \\
\hline
\end{tabular}

Berdasarkan data tersebut terlihat ketuntasan belajar siswa dua tahun terakhir pada materi reaksi redoks rendah karena untuk masing-masing kelas persentase ketuntasannya masih dibawah batas tuntas 75 .

Hasil observasi nilai Ulangan Semester Gasal siswa kelas X MIPA tahun ajaran 2016/2017 sebelum tindakan disajikan pada Tabel 2.

Tabel 2. Ketuntasan Belajar Ulangan Semester Gasal Tahun Ajaran 2016/2017

\begin{tabular}{cc}
\hline Kelas & \% Ketuntasan Belajar \\
\hline X MIPA 1 & 32,26 \\
X MIPA 2 & 31,25 \\
X MIPA 3 & 23,53 \\
X MIPA 4 & 29,41 \\
\hline
\end{tabular}

Berdasarkan tabel di atas siswa kelas X MIPA 3 menunjukkan ketuntasan belajar yang paling rendah yaitu sebesar $23,53 \%$ atau 8 siswa dari 34 siswa yang sudah mencapai batas kriteria ketuntasan belajar 75. Rendahnya prestasi belajar siswa kelas X MIPA 3 menjadikan alasan kelas ini digunakan untuk penelitian.

Aktivitas belajar siswa merupakan hal yang cukup penting dalam suatu proses pembelajaran. Dengan adanya aktivitas siswa dalam pembelajaran, kegiatan belajar di kelas menjadi lebih optimal. Meningkatnya aktivitas belajar siswa ini sejalan dengan meningkatnya pemahaman siswa terhadap materi yang dipelajari. Sardiman menyatakan ada delapan kelompok aktivitas belajar siswa antara lain : visual activities, oral activities, listening activities, writing activities, drawing activities, motor activities, mental activities, dan emotional activities [4].

Selama observasi di kelas X MIPA pada bulan September tahun ajaran 2016/2017 terlihat aktivitas belajar siswa serta tanggung jawab siswa yang rendah. Hal ini dilihat dari permasalahan yang muncul ketika pembelajaran kimia berlangsung antara lain: (1) masih terdapat banyak siswa yang belum masuk kelas, (2) siswa kurang antusias dalam mengikuti pelajaran, dilihat dari 
siswa duduk terdiam asik bermain game online atau membaca komik online, (3) ketika guru bertanya, tidak ada siswa yang sukarela menjawab. Siswa menjawab ketika guru menunjuk atau memanggil namanya, (4) siswa masih banyak yang ramai sehingga konsentrasi siswa tidak terpusat pada pelajaran, (5) terdapat siswa yang memiliki catatan kurang lengkap, (6) siswa banyak yang belum membawa buku pelajaran kimia, (7) siswa masih mengerjakan tugas yang harusnya dikerjakan di rumah.

Rendahnya aktivitas belajar siswa juga didukung dari hasil angket penilaian aktivitas belajar siswa prasiklus disajikan pada Tabel 3.

Tabel 3. Perolehan Angket Aktivitas Belajar Siswa Kelas X MIPA 3

\begin{tabular}{lc}
\hline \multicolumn{1}{c}{ Kelompok } & $\begin{array}{c}\text { Capaian Aktivitas } \\
\text { Aktivitas }\end{array}$ \\
\hline Visual & 64,34 \\
Oral & 73,62 \\
Listening & 72,06 \\
Writing & 69,30 \\
Motor & 68,57 \\
Mental & 72,43 \\
Emotional & 69,86 \\
\hline
\end{tabular}

Berdasarkan data di atas pada setiap aktivitas yang diukur ternyata menunjukkan hasil aktivitas belajar yang kurang dari $75 \%$. Oleh karena hasil belum mencapai batas tuntas guna mendukung kegiatan pembelajaran, maka semua aspek aktivitas siswa akan diukur dalam penelitian ini.

Permasalahan yang terjadi di SMAN 2 Surakarta adalah rendahnya aktivitas dan prestasi belajar siswa khususnya pada materi reaksi redoks. Salah satu model pembelajaran yang dapat digunakan untuk mengatasi masalah tersebut yaitu guided discovery learning. Pembelajaran penemuan terbimbing atau guided discovery learning merupakan pembelajaran yang membutuhkan peran guru sebagai fasilitator dalam proses pembelajarannya. Dalam pembelajaran tersebut, siswa dibimbing untuk menemukan sendiri konsep dari materi yang diajarkan di kelas [5].
Penelitian yang telah dilakukan sebelumnya menunjukkan guided discovery learning dapat meningkatkan hasil belajar siswa [6]. Metode guided discovery ini dibandingkan metode tradisional lebih efektif untuk meningkatkan pemecahan masalah, pengambilan keputusan, berpikir kritis, berpikir kreatif dan keterampilan interpersonal [7]. Metode belajar tersebut juga direkomendasikan bagi guru kimia yang mengajar di sekolah menengah untuk mengkomunikasikan konsep kimia [8]. Penerapan model discovery learning dapat meningkatkan aktivitas dan prestasi belajar siswa pada materi larutan peyangga [9].

Secara umum prosedur pembelajaran berdasarkan penemuan (discovery learning) adalah sebagai berikut: (1) simulation, (2) problem statement, (3) data collection, (4) data processing, (5) verification, (6) generalization [10].

Penggunaaan metode guided discovery direkomendasikan kepada guru sains dalam kegiatan pembelajaran dengan menyediakan lingkungan belajar yang kondusif untuk mengajar beserta media ajar yang sesuai [11]. Penggunaan metode guided discovery ini akan lebih efektif jika digunakan media pembelajaran yang sesuai. Salah satu media yang bisa dipakai untuk membantu siswa dalam pemahaman materi reaksi redoks ini yaitu media visual dua dimensi berupa kartu pembelajaran. Kartu pembelajaran yang akan digunakan ini berupa kartu yang berisi pokok-pokok materi pembelajaran sehingga proses belajar dapat berlangsung lebih efektif. Menurut hasil penelitian yang telah dilakukan bahwa penggunaan media kartu efektif untuk meningkatkan prestasi belajar kimia pada materi hidrokarbon [12].

Berdasarkan uraian di atas maka perlu dilakukan Penelitian Tindakan Kelas (PTK) untuk meningkatkan aktivitas dan prestasi belajar siswa dengan menerapkan model guided discovery learning berbantu media kartu pembelajaran pada materi pokok reaksi redoks di kelas X MIPA 3 SMA N 2 Surakarta tahun pelajaran 2016/2017. 


\section{METODE PENELITIAN}

Penelitian dilakukan di SMAN 2 Surakarta yang beralamat di Jl. Monginsidi No 40 Gilingan, Banjarsari, Surakarta. Penelitian ini merupakan Penelitian Tindakan Kelas (PTK) yang dilaksanakan dalam dua siklus, dengan tahapan yang dilalui yaitu 1) perencanaan, 2) pelaksanaan, 3) pengamatan dan 4) refleksi [13]. Subjek penelitian adalah siswa kelas X MIPA 3 SMAN 2 Surakarta tahun pelajaran 2016/2017.

Sumber data adalah guru dan siswa. Teknik pengumpulan data dalam penelitian ini melalui teknik observasi, angket, kajian dokumen dan tes [14]. Analisis data dalam penelitian tindakan kelas ini dimulai dari awal sampai berakhirnya pengumpulan data. Data hasil penelitian diolah dan dianalisis secara deskriptif kualitatif. Teknik analisis kualitatif mengacu pada model analisis spiral Miles dan Huberman yang dilakukan secara interaktif melalui proses reduksi data, penyajian data, dan penarikan kesimpulan dan verifikasi [15]. Teknik yang digunakan untuk memeriksa validitas data yang digunakan adalah triangulasi metode angket, observasi dan wawancara [16].

\section{HASIL DAN PEMBAHASAN}

Sebelum melaksanakan penelitian, dilakukan tahap persiapan melalui observasi kegiatan pembelajaran di kelas, wawancara, dan kajian dokumen. Hasil yang didapat yaitu aktivitas dan prestasi belajar siswa rendah pada materi reaksi redoks. Selain itu, dalam proses pembelajaran siswa belum dilibatkan secara langsung sehingga pembelajarannya masih berpusat pada guru. $\mathrm{Hal}$ ini menyebabkan proses pembelajaran belum berjalan efektif.

\section{Siklus I}

\section{a. Perencanaan}

Pada tahap perencanaan siklus I, dilakukan penyusunan silabus, RPP, LKS, instrumen penilaian aktivitas, serta instrumen prestasi belajar dan media kartu. Berdasarkan silabus diketahui bahwa materi redoks memiliki alokasi waktu 7 jam pelajaran (7jp). Perincian pembelajaran pada siklus I yaitu 5 jp ( $5 \times$ 45 menit) untuk penyampaian materi dan 2 jp ( $2 \times 45$ menit) untuk evaluasi siklus I.

\section{b. Pelaksanaan}

Pelaksanaan tindakan pada siklus I berlangsung pada tanggal 8 sampai 22 Februari 2017. Siklus I ini terdiri atas 4 kali pertemuan, dimana 3 pertemuan untuk penyampaian materi dan 1 kali pertemuan untuk evaluasi siklus I. Pada pertemuan awal ini dilakukan eksperimen mengetahui perkembangan konsep reaksi reduksi dan oksidasi beserta prinsip kerjanya. Pembelajaran dimulai dengan apersepsi yang disampaikan oleh guru. Setelah itu siswa dibentuk dalam kelompok, kemudian siswa diberikan suatu permasalahan lewat kegiatan praktikum dan diberikan lembar diskusi. Proses pembelajaran dilanjutkan dengan diskusi kelompok. Hasil diskusi kemudian dipresentasikan di depan kelas. Pembelajaran ditutup dengan konfirmasi hasil diskusi dan menarik kesimpulan secara bersamasama, dan diakhiri guru memberikan posttest.

Pertemuan kedua, dan ketiga secara teknis hampir sama dengan pertemuan pertama, hanya saja pada pertemuan tersebut materi pembelajaran yang disampaikan berbeda dan tidak dilakukan praktikum. Pada pertemuan terakhir atau pertemuan keempat, dilaksanakan evaluasi siklus I yang meliputi penilaian aspek pengetahuan dimana siswa harus menjawab soal ulangan dan sisa waktu yang tersisa digunakan untuk mengisi angket penilaian diri aktivitas dan aspek sikap. Sementara lembar observasi diisi oleh observer dari pertemuan pertama sampai ketiga.

\section{c. Pengamatan}

Berdasarkan hasil pengamatan data yang diperoleh dalam penelitian antara lain aktivitas dan prestasi belajar siswa meliputi aspek pengetahuan, aspek sikap dan aspek keterampilan. 
Pada penilaian aktivitas siswa dikatakan tuntas jika masuk dalam kategori sangat baik dan sangat baik. Hasil penilaian aktivitas belajar siswa lebih lengkap disajikan pada Gambar 1.

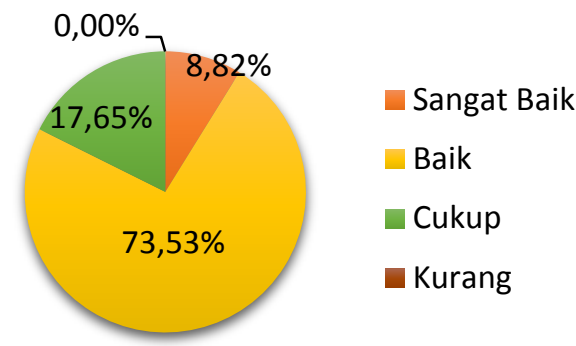

Gambar 1. Penilaian Aktivitas Siklus I

Ketuntasan aktivitas belajar siswa kelas X MIPA 3 sebesar 82,35\%. Persentase ketercapaian ini sudah memenuhi target yang ditentukan yaitu $75 \%$. Namun ketuntasan aspek aktivitas dari 7 aspek yang ada masih terdapat 1 aspek yang belum tuntas yaitu aspek mental activities. Aspek yang telah tuntas adalah visual activities, oral activities, listening activities, writing activities, motor activities dan emotional activities. Adanya aspek yang belum tuntas ini dikarenakan kurangnya rasa percaya diri siswa, siswa cenderung takut untuk mencoba dan salah. Oleh karena itu perlu dilakukan perbaikan untuk meningkatkan aktivitas pada siklus II.

Hasil penilaian pengetahuan siklus I disajikan pada Gambar 2.

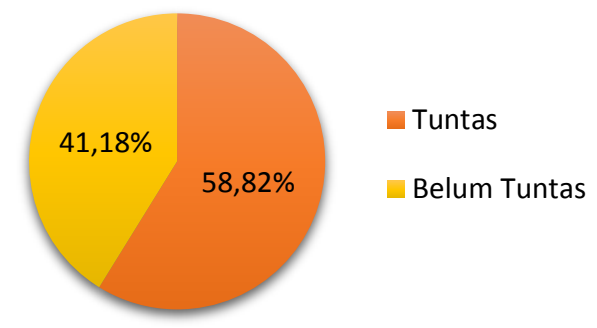

Gambar 2. Penilaian Prestasi Belajar Aspek Pengetahuan Siklus I

Gambar di atas menunjukkan bahwa siswa yang belum tuntas atau belum mencapai target sebesar $41,18 \%$ dari target yang ditentukan $75 \%$. Hasil siklus I terdapat 3 indikator yang telah memenuhi target dan 1 indikator yang belum memenuhi target. Indikator yang belum memenuhi target yaitu membedakan reaksi redoks dan bukan redoks. Penyebab indikator yang belum tuntas dikarenakan tergolong materi yang sulit bila dibanding dengan materi pada indikator yang lain dan masih banyak siswa yang kurang teliti dan kurang serius dalam mengerjakan soal. Oleh karena itu akan dilakukan penelitian di siklus II agar mencapai target yang telah ditentukan.

Hasil penilaian aspek sikap siswa disajikan pada Gambar 3.

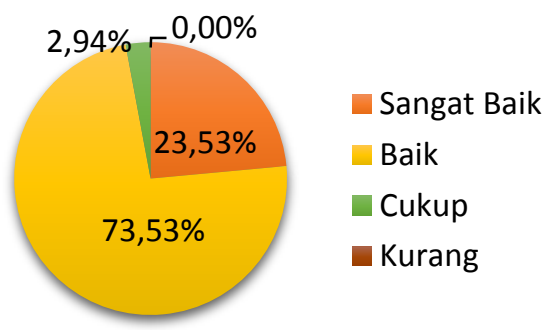

Gambar 3. Penilaian Prestasi Belajar Aspek Sikap Siklus I

Gambar di atas menunjukkan ketuntasan aspek sikap sebesar $97,06 \%$. Ketuntasan yang diperoleh merupakan akumulasi persentase siswa kategori sangat baik dan baik. Capaian hasil aspek sikap siswa juga telah memenuhi target yang ditentukan yaitu $75 \%$. Indikator dalam aspek sikap antara lain spiritual, jujur, disiplin, tanggung jawab dan toleransi. Diantara semua indikator, indikator jujur memiliki ketercapaian yang mendekati batas target yang ditentukan. Hal ini menandakan bahwa siswa kelas $X$ MIPA 3 belum bisa menerapkan kejujuran di dalam pembelajaran dengan baik.

Dalam aspek keterampilan, terdapat tiga kegiatan yang dinilai yakni melakukan percobaan, menyajikan hasil percobaan, dan menyimpulkan hasil percobaan. Hasil observasi aspek keterampilan menunjukkan bahwa seluruh siswa telah tuntas. Aspek keterampilan seluruhnya juga sudah memenuhi target yang ditentukan yakni $75 \%$ siswa tuntas.

\section{d. Refleksi}

Berdasarkan hasil pengamatan
dan evaluasi yang dilakukan
menunjukkan masih terdapat aspek yang


belum mencapai target yaitu aktivitas dan aspek pengetahuan siswa. Oleh karena itu, perlu dilaksanakan siklus II yang diharapkan dapat meningkatkan kemampuan siswa pada aspek aktivitas dan prestasi belajar siswa sehingga target yang sudah ditentukan dapat tercapai. Sementara itu aspek sikap dan keterampilan sudah memenuhi target yang ditentukan sehingga kedua aspek ini tidak dilakukan penilaian pada siklus selanjutnya.

\section{Siklus II}

\section{a. Perencanaan}

Pelaksanaan siklus II ini lebih difokuskan untuk perbaikan terhadap permasalahan yang muncul pada siklus I. Materi yang diberikan juga fokus pada indikator yang belum mencapai ketuntasan yaitu membedakan reaksi redoks dan bukan redoks. Pemberian evaluasi dibatasi hanya pada soal dengan indikator yang belum tuntas saja. Kelompok diskusi pada siklus II ini dibagi secara heterogen dan sesuai dengan nilai yang didapat siswa pada evaluasi siklus I. Hal ini dilakukan agar siswa yang sudah tuntas di siklus I dapat membantu temannya yang belum tuntas dalam satu kelompok sehingga diharapkan bisa tuntas dalam evaluasi siklus II.

\section{b. Pelaksanaan}

Siklus II ini dilaksanakan dalam 2 kali pertemuan, yaitu 1 kali pertemuan (2 jp) untuk penyampaian materi dan 1 kali pertemuan (1 jp) untuk evaluasi siklus II.

$$
\text { Pada pertemuan pertama, }
$$

sebelum masuk kegiatan pembelajaran guru mengajukan pertanyaan kemudian memotivasi siswa dan memberikan penguatan tentang pentingnya belajar reaksi redoks. Setelah itu siswa dibentuk kelompok, dan diberikan permasalahan berupa soal diskusi untuk didiskusikan secara berkelompok. Selanjutnya siswa yang telah selesai mempresentasikan hasil diskusi di depan kelas, kelompok lain menanggapi dan bertanya terkait hal yang belum dimengerti. Setelah itu pembelajaran diakhiri dengan guru bersama siswa membuat kesimpulan di akhir pembelajaran dan siswa diberikan soal posttest untuk latihan.

Pada pertemuan kedua atau pertemuan terakhir dilaksanakan evaluasi siklus II yang terdiri atas tes aspek pengetahuan berupa 10 soal objektif dan sisa waktu digunakan untuk mengisi angket aktivitas.

\section{c. Pengamatan}

Berdasarkan observasi dan analisis tes yang sudah dilakukan pada siklus II dapat dilihat hasil analisis aktivitas dan prestasi belajar siswa meliputi aspek pengetahuan. Hasil observasi dan analisis angket aktivitas belajar siswa disajikan dalam Gambar 4 .

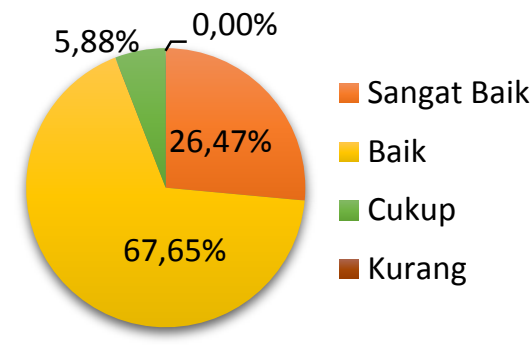

Gambar 4. Penilaian Aktivitas Siklus II

Hasil yang disajikan pada gambar 4 menunjukkan ketuntasan aktivitas siswa sebesar 94,12\%. Hasil ini merupakan akumulasi persentase siswa kategori sangat baik dan baik. Ketuntasan yang diperoleh sudah mencapai target yang ditentukan dan semua aspek melampaui target $75 \%$.

Pada penilaian prestasi belajar aspek pengetahuan didapatkan capaian aspek pengetahuan siklus ini sebesar $85,65 \%$, hasil ini sudah melampaui target sebesar $75 \%$. Semua indikator yang diujikan juga sudah mencapai target yang ditetapkan. Hasil penilaian aspek pengetahuan siklus II disajikan pada Gambar 5.

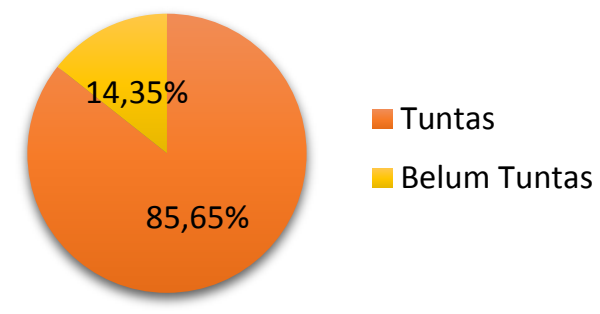

Gambar 5. Penilaian Aktivitas Siklus II 


\section{d. Refleksi}

Hasil pengamatan dan evaluasi yang telah dilaksanakan pada siklus II untuk aspek aktivitas dan pengetahuan mengalami peningkatan daripada siklus I. Ini berarti model guided discovery learning berbantu media kartu pembelajaran telah berhasil yang ditunjukkan aspek aktivitas dan prestasi belajar siswa telah memenuhi target $75 \%$ siswa tuntas sehingga pembelajaran dapat diakhiri pada siklus II.

\section{Perbandingan Antarsiklus}

Berdasarkan hasil angket, observasi, tes dan wawancara yang telah dilakukan pada siklus I dan siklus II melalui penerapan model guided discovery learning dengan bantuan media kartu pembelajaran maka hasil tersebut dapat dibandingkan untuk mengetahui peningkatan yang yang dicapai dari satu siklus ke siklus berikutnya.

Persentase ketercapaian aspek aktivitas pada siklus II mengalami peningkatan dibandingkan dengan hasil siklus I. Pada siklus I persentase ketercapaiannya sebesar $82,35 \%$ meningkat menjadi $94,12 \%$ pada siklus II. Hal tersebut terjadi karena persentase siswa kategori sangat baik meningkat diimbangi penurunan persentase siswa kategori baik dan cukup. Ketercapaian aktivitas belajar siswa pada siklus I dan siklus II disajikan pada Gambar 6 .

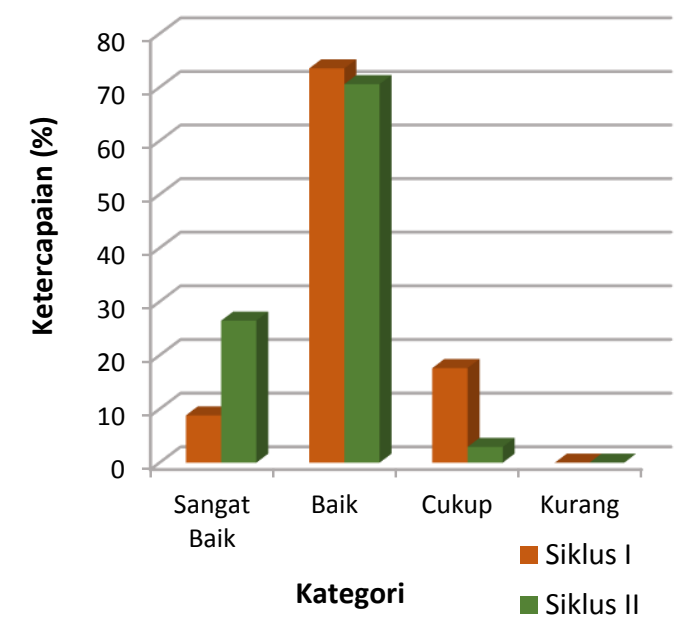

Gambar 6. Histogram Perbandingan Persentase Ketercapaian Aktivitas Siswa pada Siklus I dan II
Prestasi belajar meliputi aspek pengetahuan, aspek sikap, dan aspek keterampilan. Berdasarkan hasil tes aspek pengetahuan pada siklus I dan II, menunjukkan terjadi peningkatan persentase ketercapaian dari 58,82\% menjadi $85,65 \%$. Adapun peningkatan ketuntasan aspek pengetahuan siklus I dan siklus II disajikan pada Gambar 7

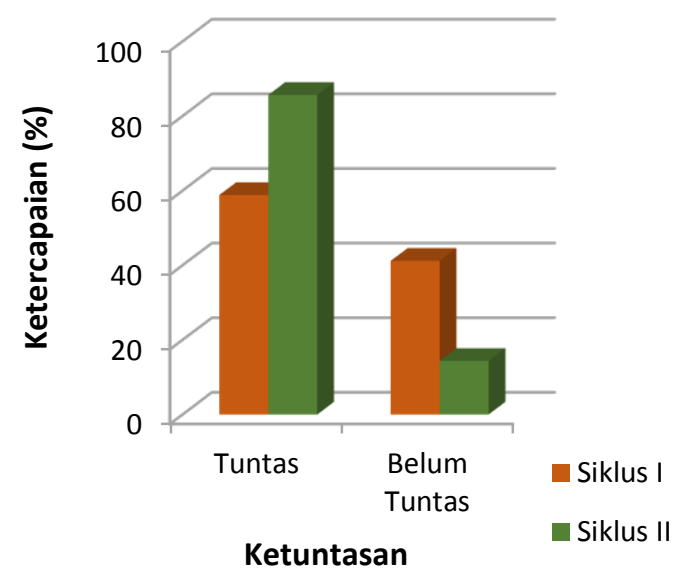

Gambar 7. Histogram Perbandingan

Persentase Ketuntasan Aspek Pengetahuan pada Siklus I dan II

Aspek sikap pada siklus I diperoleh ketercapaian sebesar 97,06\%. Hasil ini telah melampaui target yang telah ditentukan 75\%. Hasil ketercapaian aspek keterampilan pada siklus I didapatkan semua siswa telah tuntas. Hal ini membuat kedua aspek tersebut tidak dilaksanakan kembali pada siklus II.

Berdasarkan hasil tersebut, penelitian dengan menggunakan model guided discovery dengan bantuan kartu pembelajaran dikatakan berhasil karena pada akhir penelitian semua aspek telah mencapai target yang ditetapkan sehingga penelitian ini dapat meningkatkan prestasi belajar yang terdiri dari aspek sikap, pengetahuan dan keterampilan serta dapat meningkatkan proses belajar siswa yang berupa aktivitas belajar siswa.

\section{KESIMPULAN}

Berdasarkan hasil penelitian yang dilakukan penerapan model guided discovery learning berbantu media kartu pembelajaran dapat meningkatkan 
aktivitas belajar $(82,35 \%$ pada siklus I meningkat menjadi $94,12 \%$ pada siklus II) dan prestasi belajar (aspek pengetahuan pada siklus I 58,82\% meningkat menjadi $85,65 \%$ pada siklus II, aspek sikap memberikan hasil ketuntasan 97,06\% dan aspek keterampilan sebesar $100 \%$ yang dilakukan sekali pada siklus I) pada materi pokok reaksi redoks siswa kelas $X$ MIPA 3 SMAN 2 Surakarta Tahun Pelajaran 2016/2017.

\section{UCAPAN TERIMAKASIH}

Bapak Drs. Sutikno, MM, selaku Kepala Sekolah SMAN 2 Surakarta yang telah memberikan izin penelitian di SMAN 2 Surakarta, dan lbu CME Widyastuti, S.Pd, MM selaku guru kimia yang telah mengizinkan penulis menggunakan kelasnya untuk penelitian di SMAN 2 Surakarta.

\section{DAFTAR RUJUKAN}

[1] Kastberg, D., Chan, J.Y., \& Murray, G. 2016. Performance of U.S. 15Year-Old Students in Science, Reading, and Mathematics Literacy in an International Context. Washington, DC: National Center for Education Statistics.

[2] Kemendikbud. (2014). Permendikbud No. 160 Tahun 2014 tentang Pemberlakuan Kurikulum Tahun 2006 dan Kurikulum 2013. Jakarta: Kementerian Pendidikan dan Kebudayaan.

[3] Puspendik. (2015). Laporan Hasil Ujian Nasional. Diperoleh pada 18 Januari 2017 dari http:118.98.234. 50/lhun/daya_serap.aptx.

[4] Sardiman, A.M. 2004. Interaksi \& Motivasi Belajar Mengajar. Jakarta: PT Raja Grafindo Persada.
[5] Sapriati, A, dkk. 2009. Materi Pokok Pembelajaran IPA di SD. Jakarta: Universitas Terbuka.

[6] Akanmu, M. A., \& Fajemidagba, M. O. 2013. Journal of Education and Practice, 4 (12), 89.

[7] Makoolati, N., et al. 2015. Hormozgan Medical Journal, 8 (6), 541.

[8] Udo, M.E. (2010). An International Multi-Disciplinary Journal, 4 (4), 391.

[9] Istiana, G.A., Saputro, A.N.C., \& Sukardjo, J. S. 2016. JPK. 4 (2), 6573.

[10] Ahmadi, A., \& Prasetya, J. T. 1997. Strategi Belajar Mengajar. Bandung: Pustaka Setia.

[11] Nbina, J.B. 2013. Journal of Research in Education and Society, $4(1), 1$.

[12] Qurniawati, A., Sugiharto, \& Saputro, A.N.C. 2013. JPK, 2 (3), 166-174.

[13] Kasbolah, K. 2001. Penelitian Tindakan Kelas untuk Guru. Malang: Universitas Negeri Malang.

[14] Riduwan. 2012. Skala Pengukuran Variabel-Variabel Penelitian. Bandung: Alfabeta.

[15] Sugiyono. 2010. Metode Penelitian Pendidikan Pendekatan Kuantitatif, Kualitatif dan RnD. Bandung: Alfabeta.

[16] Moleong, J. L. (2008). Metodologi Penelitian Kualitatif. Bandung: PT Remaja Rosdakarya. 